\title{
Anticoagulant Activity of a Sulfated Polysaccharide Isolated from the Green Seaweed Caulerpa cupressoides
}

\author{
José Ariévilo Gurgel Rodrigues ${ }^{1}$, Edfranck de Sousa Oliveira Vanderlei ${ }^{2}$, Érika Façanha \\ Bessa $^{2}$, Francisco de Araújo Magalhães ${ }^{3}$, Regina Célia Monteiro de Paula ${ }^{3}$, Vilma Lima \\ and Norma Maria Barros Benevides ${ }^{1,2^{*}}$ \\ ${ }^{I}$ Programa de Pós-graduação em Biotecnologia; Rede Nordeste de Biotecnologia; Av. Paranjana, 1700; Fortaleza \\ - CE - Brasil. ${ }^{2}$ Departamento de Bioquímica e Biologia Molecular; Universidade Federal do Ceará; Av. Mister \\ Hull, s/n; Fortaleza - CE - Brasil. ${ }^{3}$ Departamento de Química Orgânica e Inorgânica; Av. Mister Hull, s/n; \\ Fortaleza - CE - Brasil. ${ }^{4}$ Departamento de Odontologia, Farmácia e Enfermagem; Rua Monsenhor Furtado, s/n; \\ Fortaleza-CE-Brasil
}

\begin{abstract}
The aim of this study was to evaluate certain molecular characteristics of a sulfated polysaccharide (SPS) with anticoagulant properties, isolated from Caulerpa cupressoides (Chlorophyta). Crude SPs were extracted by proteolytic digestion (papain), followed by ion-exchange chromatography on a DEAE-cellulose column. The fractions obtained were analyzed for molecular mass, $0.5 \%$ agarose gel electrophoresis and chemical composition. The activated partial thromboplastin time (APTT) test was applied using normal human plasma and standard heparin (HEP) (193 IU mg $\left.\mathrm{m}^{-1}\right)$. The yield was $\sim 3 \%$, and the chromatography procedure separated the material into three different SP fractions (F I, F II and F III), eluted at the concentrations of 0.50, 0.75 and $1.00 \mathrm{M}$ of $\mathrm{NaCl}$, respectively. Only fraction $F$ II was active (24.62 IU $\left.\mathrm{mg}^{-1}\right)$, with high sulfate content $(23.79 \%)$ and number of molecular mass peaks. Therefore, the APTT of a fraction isolated from C. cupressoides was less potent than HEP.
\end{abstract}

Key words: marine algae, sulfated macromolecules, chemical analysis, APTT test.

\section{INTRODUCTION}

Sulfated polysaccharides (SPs) are complex and heterogeneous macromolecules found at high concentrations in marine algae (Percival and McDowell, 1967; Farias et al., 2000; Melo et al., 2002; Assreuy et al., 2008; Pomin and Mourão, 2008; Rodrigues et al., 2009a). They are also known to have important ionic, mechanical and osmotic functions, and are components of the extracellular matrix (Kloareg and Quatrano, 1988; Pomin and Mourão, 2008). However, SPs are found not only in marine macroalgae, but also in microalgae (Hayashi et al., 1996), invertebrates (Mourão and Pereira, 1999) and sea grasses, as reported by Aquino et al. (2005). Vertebrates also contain SPs, known as glycosaminoglycans (Kjellèn and Lindahl, 1991; Rodrigues et al., 2009b).

In recent years, there have been reports of various biological activities of SPs isolated from different sources, including marine algae (Leite et al., 1998; Farias et al., 2001; Mazumder et al., 2002; Qi et al., 2005; Lins et al., 2009; Ananthi et al., 2010;

*Author for correspondence: nmbb@ufc.br 
Rodrigues et al., 2011), echinoderms, tunicates (Mourão and Pereira, 1999; Pomin and Mourão, 2008) and fishes (Mansour et al., 2009; Rodrigues et al., 2009b). Anticoagulant and antithrombotic activities are among the most widely studied properties of marine algae (Farias et al., 2000; Pereira et al., 2002; Mourão, 2004; Pereira et al., 2005; Athukorala et al., 2006; Fonseca et al., 2008; Pushpamali et al., 2008; Rodrigues et al., 2009a). As a rule, molecular size and sulfate content are among the most important prerequisites for these polymers to have anticoagulant activity (Nishino et al., 1991; Farias et al., 2000; Mourão, 2004; Pomin and Mourão, 2008; Pushpamali et al., 2008). Some studies have also reported the use of SP extracts to prevent the stress and control infectious diseases in aquatic farming (Fu et al., 2007; Rodrigues et al., 2009c). In addition, seaweeds have been considered a rich source of SPs known as phycocolloids, with thickening, gelling and stabilizing properties in several other biotechnology applications (Campo et al., 2009). It has encouraged to cultivate native seaweeds in Brazil (Salles et al., 2010; Rodrigues et al., 2011).

There are few reports of anticoagulant activity for SPs isolated from green algae. Matsubara et al. (2000) isolated a highly sulfated galactoarabinoglucan from the green alga Codium pugniformis, with anticoagulant activity. A sulfated galactan with anticoagulant activity was also extracted from Codium cylindricum (Matsubara et al., 2001). Caulerpa racemosa contains SPs with anticoagulant and antiviral activities (Ghosh et al., 2004). Recently, anticoagulant SPs isolated from marine green algae of the Monostroma genus were reported by Mao et al. (2008) and Zhang et al. (2008).

Cardiovascular disease is the leading cause of death worldwide. The therapeutic use of heparin, an SP isolated from pig intestines or cattle lungs, is also limited due to its side effects and other complications, such as the risk of hemorrhage (Mourão and Pereira, 1999; Nader et al., 2001).

In this context, there is a great need for new compounds from natural sources. In this regard, marine green algae could be a promising potential source. Caulerpa spp., belonging to the Caulerpaceae family, are commonly found along the northeastern Brazilian coast. In this study, SP fractions were obtained from the marine green alga Caulerpa cupressoides, and some characteristics and potential anticoagulant properties of the polysaccharides were investigated.

\section{MATERIALS AND METHODS}

\section{Reagents}

Cetylpyridinium chloride (CPC); cysteine; 1,9dimethylmethylene blue (DMB); 1,3diaminopropane, DEAE cellulose (Sigma Chemical Co., St. Louis, MO, U.S.A.; or Sigma Aldrich Chemie, Steinheim, Germany); ethylenediaminetetraacetic acid (EDTA) (QEEL, São Paulo, SP, Brazil); glacial acetic acid; $N$-cetyl$N, N, N$-trimethyl-ammonium bromide; sodium acetate; toluidine blue; papain (Vetec Química, São Paulo, SP, Brazil); agarose gel (BioAgency, São Paulo, SP, Brazil); APTT; PT and calcium chloride kits (CLOT BIOS Diagnóstica, Sorocaba, SP, Brazil), and unfractionated heparin from the National Institute for Biological Standards and Control, Potters Bar, Hertfordshire, UK.

\section{Marine alga}

The marine green alga Caulerpa cupressoides (Vahl) C. Agardh (Caulerpaceae, Chlorophyta) was collected from Pacheco Beach (Caucaia, Ceará State, Brazil). The material was cleaned of epiphytes, washed with distilled water and stored at $-20^{\circ} \mathrm{C}$ until use. A voucher specimen (4977) was classified and archived by Ana Cecília Fortes Xavier at the Prisco Bezerra Herbarium, Federal University of Ceará.

\section{Isolation of enzymatic SPs}

SPs were isolated according to the method of Farias et al. (2000). Briefly, the algae were dehydrated at $25^{\circ} \mathrm{C}$ and macerated with liquid nitrogen. The dried tissue $(5 \mathrm{~g})$ was subjected to digestion with crude papain solution $\left(30 \mathrm{mg} \mathrm{mL}^{-1}\right)$ in $250 \mathrm{~mL} 0.1 \mathrm{M}$ sodium acetate buffer (pH 5.0) containing $5 \mathrm{mM}$ cysteine and $5 \mathrm{mM}$ EDTA at $60^{\circ} \mathrm{C}$ for $6 \mathrm{~h}$. The material was then centrifuged $\left(2295 \times g ; 30 \mathrm{~min} ; 10^{\circ} \mathrm{C}\right)$, and $16 \mathrm{~mL} 10 \% \mathrm{CPC}$ solution was added to the supernatant to precipitate the crude SP ( $\mathrm{cSP}$ ) by keeping at room temperature for $24 \mathrm{~h}$. By centrifugation as above, the pellet was separated from this solution and washed with $200 \mathrm{~mL} 0.05 \%$ CPC, dissolved in a mixture of $100 \mathrm{~mL} 2 \mathrm{M} \mathrm{NaCl}$ :commercial ethanol $(100: 15 ; \mathrm{v} / \mathrm{v})$ and the polysaccharides were submitted to a second precipitation by adding 
$200 \mathrm{~mL}$ commercial ethanol and keeping at $4^{\circ} \mathrm{C}$ for $24 \mathrm{~h}$. The pellet was then concentrated by centrifuging, washed twice with $200 \mathrm{~mL} 80 \%$ ethanol and once with $150 \mathrm{~mL}$ commercial ethanol, and finally dialyzed against distilled water for $24 \mathrm{~h}$ prior to lyophilization, in order to obtain the cSP.

\section{Ion-exchange chromatography}

A sample of cSP from C. cupressoides $(30 \mathrm{mg}$ ) was dissolved in $0.05 \mathrm{M}$ sodium acetate buffer and then fractionated by ion-exchange chromatography on a DEAE-cellulose column $(16.5 \times 1.3 \mathrm{~cm})$, previously equilibrated and washed with the same buffer, followed by separation of SP fractions, also using the same buffer containing $\mathrm{NaCl}$ at different concentrations $(0.50,0.75$ and $1.00 \mathrm{M})$. SP fractions $(5 \mathrm{~mL})$ were collected and monitored by metachromatic property using DMB (Farndale et al., 1986) with an Amersham Biosciences Utrospec 1100 spectrophotometer at $525 \mathrm{~nm}$; total carbohydrates was determined according to Dubois et al. (1956) on a microplate format (Masuko et al., 2005) using an ELISA reader (Amersham Biosciences, Biotrak II) at $492 \mathrm{~nm}$. The metachromatic fractions were then dialyzed and freeze-dried.

\section{Molar mass distribution}

The peak molar masses were estimated by gel permeation chromatography (GPC) with a Shimadzu apparatus at room temperature using an Ultrahydrogel linear column $(7.8 \times 300 \mathrm{~mm})$, flow of $0.5 \mathrm{~mL} \mathrm{~min}^{-1}, \quad 0.5 \%$ polysaccharide concentration for each SP fraction obtained from the DEAE-cellulose column, and $0.1 \mathrm{M} \mathrm{NaNO}_{3}$ as solvent. A differential refractometer and an ultraviolet photometer (at $280 \mathrm{~nm}$ ) were used as detectors, and the elution volume was corrected to the internal marker of ethylene glycol at $11.25 \mathrm{~mL}$. Pullulan samples (Shodex Denko) with molar masses $5.9 \times 10^{3}, 1.18 \times 10^{4}, 4.73 \times 10^{4}, 2.12 \times$ $10^{5}$ and $7.88 \times 10^{5} \mathrm{~g} \mathrm{moL}^{-1}$ were used as standards (Melo et al., 2002).

\section{Agarose gel electrophoresis}

The cSP and SP fractions eluted in the DEAEcellulose column were analyzed by $0.5 \%$ agarose gel electrophoresis according to Dietrich and Dietrich (1976). Samples of each SP fraction (25 $\mu \mathrm{g})$ were applied to a gel and run for $1 \mathrm{~h}$ at $110 \mathrm{~V}$ in $0.05 \mathrm{M} 1.3$ diaminopropane-acetate buffer $(\mathrm{pH}$ 9.0). SPs on gel were fixed with $0.1 \% N$-cetyl- $N$ -
$N$ - $N$-trimethyl-ammonium bromide solution. After $12 \mathrm{~h}$, the gel was dried and stained with $0.1 \%$ toluidine blue and discolored with an acetic acid:absolute ethanol:distilled water solution (0.1:0.45:0.45).

\section{Chemical analysis}

Total sugars (TS) content was estimated by phenol-sulfuric acid analysis using D-galactose as the standard (Dubois et al., 1956) on a microplate format (Masuko et al., 2005) using an ELISA reader. After acid hydrolysis of the soluble polysaccharides $\left(1 \mathrm{~mL} \mathrm{HCl}\right.$ for $5 \mathrm{~h}$ at $\left.100^{\circ} \mathrm{C}\right)$, free sulfate (FS) was measured by the $\mathrm{BaCl}_{2}$-gelatin method (Dodgson and Price, 1962). The contaminant proteins $(\mathrm{CP})$ content was measured by Bradford assay (1976), using bovine serum albumin to construct the standard curve.

\section{Evaluation of Activated Partial Thromboplastin Time (APTT)}

All clotting assays were carried out using normal citrated human plasma (11 different donors) according to the manufacturers' specifications. For this, $50 \mu \mathrm{L}$ of citrated normal human plasma was mixed with $10 \mu \mathrm{L}$ of a solution of different polysaccharide amounts before adding $50 \mu \mathrm{L}$ of APTT reagent. The mixture was then incubated at $37^{\circ} \mathrm{C}$ for $3 \mathrm{~min}$. Then, $50 \mu \mathrm{L}$ of $0.025 \mathrm{M}$ calcium chloride reagent was added to the mixture to trigger the coagulation cascade. The clotting time was recorded in a coagulometer (Drake Quick Timer). Heparin with 193 international units per $\mathrm{mg}$ (IU mg $\mathrm{mg}^{-1}$ of polysaccharide was used as the standard. All the tests were performed in triplicate.

\section{Evaluation of Prothrombin Time (PT)}

All clotting assays were carried out using normal citrated human plasma according to the manufacturers' specifications. For this, $50 \mu \mathrm{L}$ of human plasma was mixed with $10 \mu \mathrm{L}$ of a solution of different amounts of polysaccharide and incubated at $37^{\circ} \mathrm{C}$ for $3 \mathrm{~min}$. Then, $50 \mu \mathrm{L}$ of 0.025 $\mathrm{M}$ PT reagent was added to the mixture to trigger the coagulation cascade. The clotting time was again recorded using a coagulometer (Drake Quick Timer).

\section{NMR spectroscopy}

The ${ }^{13} \mathrm{C}$ NMR spectrum of SP eluted at $0.75 \mathrm{M}$ of salt (fraction F II, $50 \mathrm{mg}$ ) was analyzed. ${ }^{13} \mathrm{C}$ NMR spectra of $2.5 \% \mathrm{w} \mathrm{v}^{-1}$ solutions in $\mathrm{D}_{2} \mathrm{O}$ at room temperature were recorded in a Bruker advance DRX 500 spectrometer at $40^{\circ} \mathrm{C}$. 


\section{RESULTS AND DISCUSSION}

\section{Yield}

In the present study, the yield of enzymatically hydrolyzed polysaccharides was $\sim 3.0 \%$. The yield was similar to those from red seaweeds Gelidium crinale (2.60\%) (Pereira et al., 2005) and Botryocladia occidentalis $(4.00 \%)$ (Farias et al., 2000), but lower than those of Gracilaria cornea (21.40\%) (Melo et al., 2002), Champia feldmannii (36.20\%) (Assreuy et al., 2008) and Halymenia pseudofloresia (47.14\%) (Rodrigues et al., 2009a). Athukorala et al. (2006) obtained a polysaccharide yield of $41.52 \%$ from Ecklonia cava (Phaeophyta). According to Campo et al. (2009), current research goals are focused on identifying new natural compounds from low-cost sources for different industrial applications.
It has been reported that SPs yields could vary among different species and extraction methods (Percival and McDowell, 1967; Rodrigues et al., 2011).

\section{Ion-exchange chromatography}

A sample of the SP extract was submitted to ionexchange chromatography on the DEAE-cellulose column procedure. The DEAE-cellulose chromatography profile is shown in Fig. 1. The fraction F II had the highest dosage of sugars when compared to its metachromasia. The highest SP yield was also obtained in fraction F II, eluted with $0.75 \mathrm{M}$ of salt, compared to fractions F I and F II. The yields were 24.35, 16.36 and $3.74 \%$, respectively (Table 1).

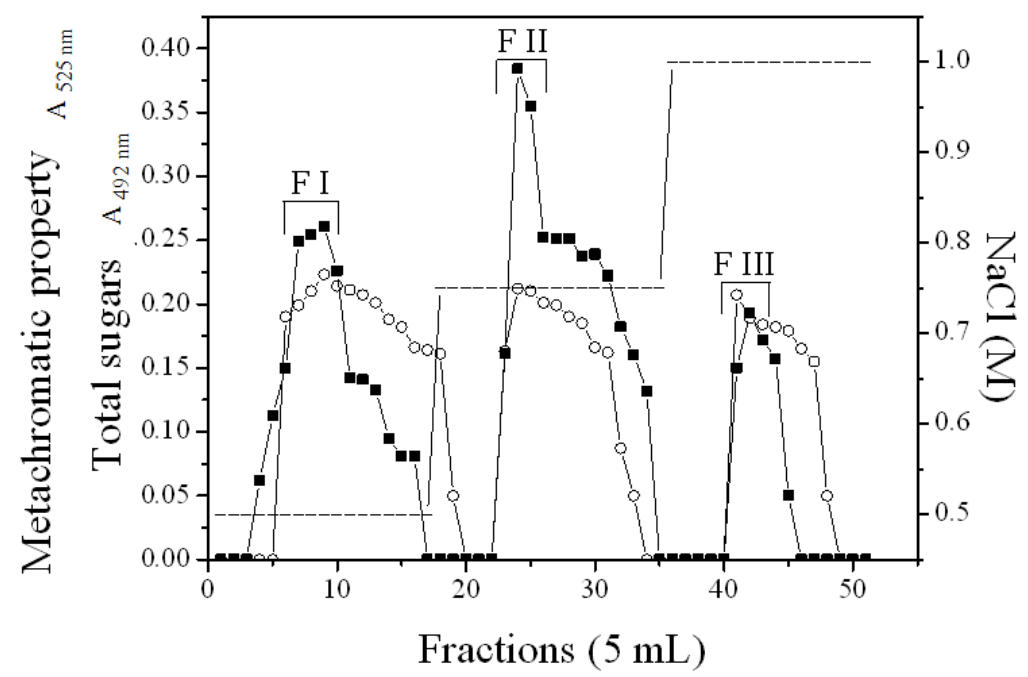

Figure 1 - Separation of sulfated polysaccharides from $C$. cupressoides by DEAE-cellulose. Fractions were collected and checked by metachromasia using 1,9-dimethymethylene blue $(\mathrm{O}-\mathrm{O})$ and phenol- $\mathrm{H}_{2} \mathrm{SO}_{4}(-\mathbf{-})$. Vertical steps represent the $\mathrm{NaCl}$ concentration (---).

The employment of DEAE-cellulose as a matrix has been widely reported for SP separation, and also to reveal the characteristics of different algae species, such as on Gelidium crinale (Pereira et al., 2005), Ecklonia cava (Athukorala et al., 2006), Champia feldmannii (Assreuy et al., 2008) and Halymenia pseudofloresia (Rodrigues et al., 2009a).

Therefore, the isolation of these compounds could be a useful tool for biological studies. Considerable structural variation occurs among the polysaccharides obtained from different species and collected from different environments or periods of the year, contributing to the highly heterogeneous and complex nature of these compounds from marine algae (Percival and McDowell, 1967; Farias et al., 2000; Melo et al., 2002). This hampers better comprehension of the structure/activity relationships (Pereira et al., 1999; Mourão and Pereira, 1999; Mourão, 2004; Fonseca et al., 2008; Mao et al., 2008; Zhang et al., 2008; Rodrigues et al., 2009a). 


\section{Molar mass distribution}

The GPC chromatograms of SP fractions obtained from the DEAE-cellulose column are shown in Fig 2. Both the fractions eluted with 0.50 and $1.00 \mathrm{M}$ of salt (fractions F I and F II) (Figs 2A and 2C) had two peaks, at 16.86 and $20.05 \mathrm{~mL}$ (peaks I and II), respectively, when detected by refraction index measurements, whereas fraction F II $(0.75 \mathrm{M}$ of salt) showed four peaks (Fig. 2B): a shoulder at $16.38 \mathrm{~mL}$ (peak I) and the others corresponding to 18.20, 20.10 and $20.90 \mathrm{~mL}$ (peaks II, III and IV), appearing when ultraviolet detection was used.

The results suggested that $C$. cupressoides SPs behaved as heterogeneous systems similar to other natural polysaccharides identified from Gracilaria cornea (Melo et al., 2002), Monostroma latissimum (Zhang et al., 2008) and M. nitidum (Karnjanapratum and You, 2011).

Fraction F II obtained from the DEAE-cellulose column had high-molecular-weight macromolecules or aggregation between the macromolecules. This agreed with the findings of Melo et al. (2002), in which a molar mass peak shoulder was also observed for G. cornea. Fraction F II of C. cupressoides was probably a polysaccharide-protein complex (proteoglycan).
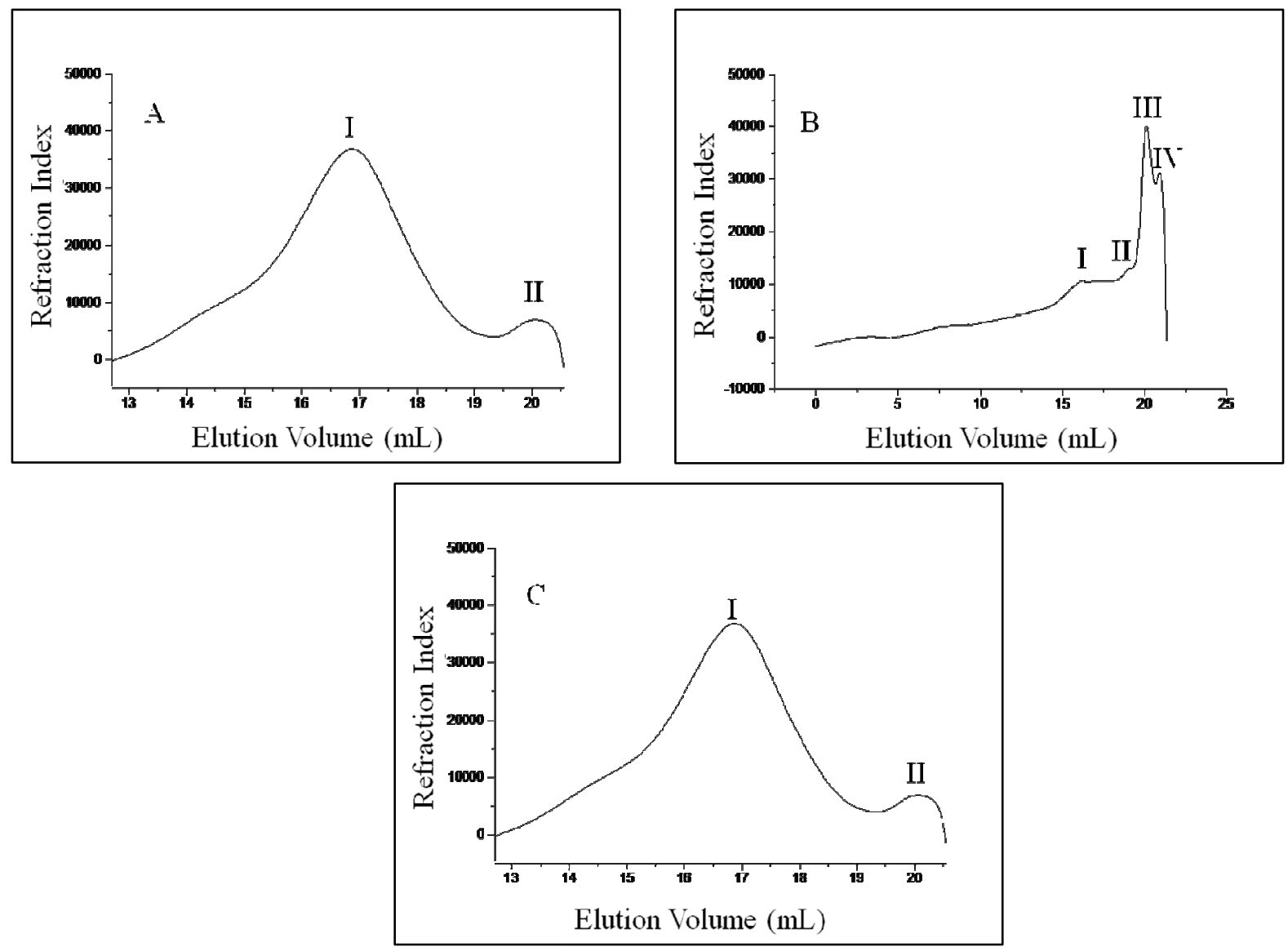

Figure 2 - Gel permeation chromatography curves of fractions F I (A), F II (B) and F III (C) obtained on a DEAE-cellulose column for $C$. cupressoides enzymatic sulfated polysaccharide solutions in $0.1 \mathrm{M} \mathrm{NaNO}_{3}$.

\section{Chemical analysis}

The chemical composition varied among the fractions, and showed that the fraction obtained with $0.75 \mathrm{M} \mathrm{NaCl}$ (fraction F II) by ion-exchange chromatography on DEAE cellulose had the highest content of TS (58.08\%) and FS (23.79\%).
CPs were not detected, demonstrating the efficacy of the extraction method used (Rodrigues et al., 2011) (Table 1). Additionally, the same fraction eluted at $0.75 \mathrm{M} \mathrm{NaCl}$ (fraction F II) presented the highest TS peak detected by the Masuko et al. (2005) method performed on an ELISA plate 
(Fig. 1). It also justified the highest TS content among the fractions obtained (Table 1) and the differential chromatographic molecular mass profile compared to fractions F I and F III (Fig. 2). These results indicated that the different GPC profile of fraction F II could not be associated with a proteoglycan form, but rather with its charge density and/or some kind of monosaccharide present in the structure. According to Ghosh et al. (2004), the hot water polysaccharides from C. racemosa were separated by size exclusion with Sephacryl S-1000 into fractions F I and F II, and it was noted that the polysaccharides containing sulfated groups presented a different rate of elution than expected on the basis of their molecular weight. This was justified due to intramolecular electrostatic repulsions by charge effects, which could perhaps confirm the GPC profiles obtained here (Fig. 2). The Caulerpa polysaccharides also consisted mainly of galactose, small amounts of glucose, xylose, manose and arabinose (Hayakawa et al., 2000; Ghosh et al., 2004).

Pushpamali et al. (2008) reported that the polysaccharide from the red alga Lomentaria catenata was composed mainly of galactose and had high sulfate content $(21.76 \%)$. Furthermore, this same polysaccharide showed a protein content of $9.42 \%$, suggesting it is also a proteoglycan. Zhang et al. (2008), employing hot aqueous extraction followed by purification, respectively, on ion-exchange and size exclusion chromatography procedures, isolated five highly charged SP fractions from the marine green alga $M$. latissimum. The polysaccharide fragments ranged from 10.6 to $216.4 \mathrm{kDa}$ (22.71 to $27.28 \%$ of sulfate). These values were different when compared to Chlorophyta from other species.

The results of this study suggested that $C$. cupressoides biosynthesized low quantities of cSP, but with fractions rich in sulfate (Table 1). However, the chemical composition of these compounds can vary due to, for instance, temperature, light and water nutrients, as well as location and season of the year (Percival and McDowell, 1967). Thus, a more detailed study of these macromolecules is recommended.

Table 1 - Yield and chemical composition of sulfated polysaccharide fractions obtained by ion-exchange chromatography (DEAE-cellulose) from C. cupressoides.

\begin{tabular}{cccccc}
\hline \multirow{2}{*}{ Fractions } & \multirow{2}{*}{ NaCl $(\mathbf{M})$} & Yield $(\%)$ & \multicolumn{3}{c}{ Chemical composition (\%) } \\
\cline { 4 - 6 } & & 16.36 & $*$ TS & * FS & * CP \\
\hline F I & 0.50 & 24.35 & 58.77 & 18.09 & - \\
F II & 0.75 & 3.74 & 19.45 & 23.79 & - \\
F III & 1.00 & & 15.43 & - \\
\hline
\end{tabular}

*Results are a mean of three determinations; - : not detected.

\section{Agarose gel electrophoresis}

The electrophoretic profile is shown in Fig. 3. The agarose gel electrophoresis procedure also showed marked differences in the charge density among the isolated fractions. This was corroborated by the sulfate content (Table 1). Thus, fractions F I and F III were not observed on agarose gel, suggesting that there were almost no sulfated groups in the chemical structure.

Conversely, fraction F II, eluted with $0.75 \mathrm{M}$ of salt, had a strong metachromatic band (Fig. 3).

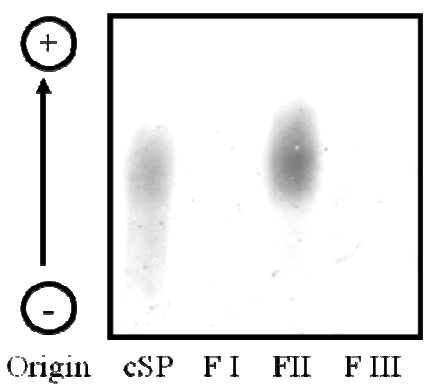

Figure 3 - Agarose gel electrophorese of sulfated polysaccharides isolated from C. cupressoides. Fractions (F I, F II and F III) and crude sulfated polysaccharide (cSP) present on gel were stained with $0.1 \%$ toluidine blue. 
Moreover, this band was a homogeneous polysaccharide when compared to cSP. This suggested that the ion-exchange chromatography procedure was efficient in purifying $C$. cupressoides SPs (Fig. 1). The polysaccharide pattern shown by the electrophoresis technique led us to conduct anticoagulant assays.

\section{Anticoagulant assays}

It is accepted that there is need to discover the new anticoagulant compounds (Mourão and Pereira, 1999); polysaccharides are a potentially attractive source of macromolecules to investigate (Farias et al., 2000; Athukorala et al., 2006; Assreuy et al., 2008; Fonseca et al., 2008; Pomin and Mourão, 2008; Pushpamali et al., 2008; Rodrigues et al., 2009a).

The anticoagulant activity of purified SPs is normally measured by different in vitro assays. The most employed of the two is the activated partial thromboplastin time (APTT) test, which indicates the precise anticoagulant potency of the compound (Mourão and Pereira, 1999).

The data obtained here showed that among all the tested SP fractions from $C$. cupressoides, only fraction F II was capable of increasing the normal coagulation time up to a polysaccharide concentration of $100 \mu \mathrm{g} \mathrm{mL} \mathrm{m}^{-1}$, and of duplicating the APTT time up to a high polysaccharide concentration $\left(250 \mu \mathrm{g} \mathrm{mL}^{-1}\right)$ in relation to normal APTT time.

Compared to standard HEP (193 IU mg ${ }^{-1}$ ), the fraction eluted with $0.75 \mathrm{M}$ of salt (fraction F II) obtained by the DEAE-cellulose procedure was an active anticoagulant enzymatic polysaccharide, and expressed in a dose-dependent manner (24.62 IU mg ${ }^{-1}$ ) (Table 2). No prolongation compared to control time (12.80 s) was observed until reaching a concentration of $1000 \mu \mathrm{g} \mathrm{mL}^{-1}$ in the PT test. The APTT test suggested that the anticoagulant polysaccharide isolated from $C$. cupressoides acted on intrinsic and/or common pathways, whereas the PT test indicated that the compound did not act on extrinsic pathways on the coagulation cascade (Athukorala et al., 2006; Pushpamali et al., 2008; Mao et al., 2008; Zhang et al., 2008; Rodrigues et al., 2009a). However, the polysaccharide isolated by proteolytic digestion had a low anticoagulant potential.

Table 2 - Anticoagulant activity of a SP fraction obtained by ion-exchange chromatography (DEAE-cellulose) from C. cupressoides compared to HEP.

\begin{tabular}{cccccccc}
\hline \multirow{2}{*}{ Fraction } & \multirow{2}{*}{$\mathrm{NaCl}(\mathrm{M})$} & $\begin{array}{c}1.00 * * \\
\mathrm{mg} \mathrm{mL}^{-1}\end{array}$ & $\begin{array}{c}0.75 * * \\
\mathrm{mg} \mathrm{mL}^{-1}\end{array}$ & $\begin{array}{c}0.50 * * \\
\mathrm{mg} \mathrm{mL}^{-1}\end{array}$ & $\begin{array}{c}0.25 * * \\
\mathrm{mg} \mathrm{mL}^{-1}\end{array}$ & $\begin{array}{c}0.10 * * \\
\mathrm{mg} \mathrm{mL}^{-1}\end{array}$ & $\mathrm{IU} \mathrm{mg}^{-1}$ \\
\hline F I & 0.50 & - & - & - & - & - & - \\
F II & 0.75 & $223.02 \mathrm{~s}$ & $103.65 \mathrm{~s}$ & $87.35 \mathrm{~s}$ & $59.49 \mathrm{~s}$ & $45.13 \mathrm{~s}$ & 24.62 \\
F III & 1.00 & - & - & - & - & - & - \\
\hline *APTT in seconds; **SP concentration to prolong the APTT; ***Activity express in international units (IU) per mg of SP; - \\
Without activity; HEP (193 IU mg ${ }^{-1} ; 0.01 \mathrm{mg} \mathrm{mL}^{-1}$; APTT: $40.17 \mathrm{~s}$ ); Control: $35.70 \mathrm{~s}$.
\end{tabular}

The isolation of SPs from different algae species demonstrated that each polysaccharide had a particular biological action, and as a consequence of the presence of sulfate radicals, these compounds should be evaluated using different assays. It has been believed that Caulerpa polysaccharides consist mainly of galactose and have specific heparin cofactor II-dependent thrombin inhibition (Hayakawa et al., 2000). This may be an important tool to design novel anticoagulants (Matsubara et al., 2001).

A SP isolated from B. occidentalis (Rhodophyta) by Farias et al. (2000) consisted of one-third 2-0sulfated units and another one-third of 2-0-sulfated units with anticoagulant activity (150.00 $\mathrm{IU} \mathrm{mg}^{-1}$ ) similar to unfractionated HEP (193.00 IU mg ${ }^{-1}$ ).
The authors also performed experiments using SP from invertebrates, and observed that the addition of two sulfate esters to a single $\alpha$-galactose residue had an "amplifying effect" on the anticoagulant action. When this polysaccharide was used in a thrombosis model, a potent antithrombotic effect on rats was also noted at a dose of $0.2 \mathrm{mg} \mathrm{kg}^{-1}$ (Farias et al., 2001).

Fonseca et al. (2008), continuing the studies of Farias, compared the SP of B. occidentalis to that isolated by Pereira et al. (2005) from G. crinale and also featuring the anticoagulant activity (65 IU $\mathrm{mg}^{-1}$ ) in specific coagulation assays and experimental thrombosis models. The results indicated that slight differences in the proportion and/or distribution of sulfated residues in these 
polysaccharide chains could be critical for the interaction of proteases, inhibitors and activators of the coagulation system, thus resulting in a distinct pattern of anti- and procoagulant activities and in antithrombotic action.

Mourão and Pereira (1999) suggested the tests of various SPs from different-origin tissues in experimental animal models. The purpose of these studies was to compare the doses required to inhibit the thrombosis, followed by the analyses of the importance of the compound isolated in the persistence of the effect, plasma circulation levels, correlation between anticoagulant action and antithrombotic effect, bioavailability and absorption when administered by different routes. In addition, the wide diversity of the polysaccharides from marine algae and invertebrates can help elucidate structural/anticoagulant activity relationships.

In contrast, for green algae it has been difficult to relate SP structure and activity (Mao et al., 2008; Zhang et al., 2008). Some authors have reported that molecular size, sulfate content, sulfation positions and linkage pattern of certain sugar residues might also have an important effect on anticoagulant activity (Nishino et al., 1991; Pereira et al., 1999; Farias et al., 2000; Mourão, 2004; Mao et al., 2008; Zhang et al., 2008).

The results of the present study also suggested that the presence or absence of anticoagulant activity among fractions obtained by ion-exchange chromatography (DEAE-cellulose) from the green alga $C$. cupressoides could probably be explained by the effect of charge density on the chemical structure. This corroborated similar descriptions for Chlorophyceae in the literature. Thus, fraction F II, eluted with $0.75 \mathrm{M}$ of salt, showed activity dependent on sulfate content and possibly molecular size (Figs. 2 and 3, and Tables 1 and 2). Other studies have evaluated the antiviral activity of SPs from seaweeds against the herpes simplex virus (Ghosh et al., 2004), and some with SPs isolated from these organisms devoid of anticoagulant activity (Mazumder et al., 2002).

Therefore, the chemical characteristics of SP fractions from $C$. cupressoides could be an important tool in different biological assays. Although NMR spectroscopy of this polysaccharide was carried out (fraction F II, eluted with $0.75 \mathrm{M}$ of salt), low absorption signals were obtained in the spectra (data not shown). Its structural study has been difficult. The structural analysis of this polysaccharide by infrared and mass spectrometry also suggested the need for further studies, not only to investigate the structural conformation but also to elucidate the compound's mechanism of action, including animal studies (Melo and Mourão, 2008).

\section{ACKNOWLEDGMENTS}

This study was supported by the grants from the National Scientific and Technological Development Council (CNPq), Northeast Biotechnology Network (RENORBIO), Coordination for the Improvement of Higher Education Personnel (CAPES) and Ceará State Scientific and Technological Development Foundation (FUNCAP). de Paula, R. C. M. and Benevides, N. M. B. are seniors investigators of $\mathrm{CNPq} / \mathrm{Brazil}$.

\section{REFERENCES}

Ananthi, S.; Raghavendran, H.R.B.; Sunil, A.G.; Gayathri, V.; Ramakrishnan, G. and Vasanthi, H.R. (2010), In vitro antioxidant and in vivo antiinflammatory potential of crude polysaccharide from Turbinaria ornata (Marine Brown Alga). Food Chem. Toxicol., 48, 187-192.

Aquino, R.S.; Landeira-Fernandez, A.M.; Valente, A.P.; Andrade, I.R. and Mourão, P.A.S. (2005), Occurrence of sulfated galactans in marine angiosperms: evolutionary implications. Glycobiol., 15, 11-20.

Assreuy, A.M.S.; Gomes, D.M.; Silva, M.S.J.; Torres, V.M.; Siqueira, R.C.L.; Pires, A.F.; Criddle, D.N.; Alencar, N.M.N.; Cavada, B.S.; Sampaio, A.H. and Farias, W.R.L. (2008), Biological effects of a sulfated-polysaccharide isolated from the marine red algae Champia feldmannii. Biol. \& Pharm. Bull., 31, 691-695.

Athukorala, Y.; Jung, W.K.; Vasanthan, T. and Jeon, Y.J. (2006), An anticoagulative polysaccharide from an enzymatic hydrolysate of Ecklonia cava. Carbohydr. Polym., 66, 184-191.

Bradford M. M. (1986), A rapid and sensitive method for the quantification of microgram quantities of protein utilizing the principle of protein-dye binding. Anal. Biochem., 22, 248-254.

Campo, V.L.; Kawano, D.F.; Silva, D.B. and Carvalho, I. (2009), Carrageenans: Biological properties, chemical modifications and structural analysis - a review. Carbohydr. Polym., 77, 167-180. 
Dietrich, C.P. and Dietrich, S.M.C. (1976), Electrophoretic behavior of acidic mucopolysaccharides in diamine buffers. Anal. Biochem., 70, 645-647.

Dodgson, K.S. and Price, R.G. (1962), A note on the determination of the ester sulfate content of sulfated polysaccharides. Biochem. J., 84, 106-110.

Farias, W.R.L.; Valente, A.P.; Pereira, M.S. and Mourão, P.A.S. (2000), Structure and anticoagulant activity of galactans: isolation of a unique sulfated galactan from the red algae Botryocladia occidentalis and comparison of its anticoagulant action with that of sulfated galactans from invertebrates. J. Biol. Chem., 275, 29299-29307.

Farias, W.R.L.; Nazareth, R.A. and Mourão, P.A.S. (2001), Dual effects of sulfated D-galactans from the red alga Botryocladia occidentalis thrombosis and inducing platelet aggregation. Thromb. Haemost., 86, 1540-1546.

Farndale, R.W.; Buttle, D.J. and Barrett, A.J. (1986), Improved quantitation and discrimination of sulfated glycosaminoglycans by use of dimethylmethylene blue. Biochm. Biophys. Acta, 883, 173-177.

Fonseca, R.J.C.; Oliveira, S.N.M.C.G.; Melo, F.R.; Pereira, M.G.; Benevides, N.M.B. and Mourão, P.A.S. (2008), Slight differences in sulfatation of algal galactanas account for differences in their anticoagulant and venous antithrombotic activities. Thromb. Haemost., 99, 539-545.

Fu, W.; Hou, W.Y.; Yeh, S.T.; Li, C.H. and Chen, J.C. (2007), The immunostimulatory effects of hot-water extract of Gelidium amansii via immersion, injection and dietary administration on white shrimp Litopenaus vannamei and its resistance against Vibrio alginolyticus. Fish \& Shell. Immunol., 22, 673-685.

Ghosh, P.; Adhikari, U.; Ghossal, P.K.; Pujol, C.A.; Carlucci, M.J.; Damonte, E.B. and Ray, B. (2004), In vitro anti-herpetic activity of sulfated polysaccharide fractions from Caulerpa racemosa. Phytochem., 65, 3151-3157.

Hayashi, K.; Hayashi, T. and Kojima, I. (1996), A natural sulfated polysaccharide, calcium spirulan, isolated from Spirulina platensis: in vitro and ex vivo evaluation of anti-herpes simplex virus and antihuman immunodeficiency virus activities. Aids Res. Hum. Retrov., 12, 1463-1471.

Hayakawa, Y.; Hayashi, T.; Lee, J.B.; Srisomporn, P.; Maeda, M.; Ozawa, T. and Sakuragawa, N. (2000), Inhibition of thrombin by sulfated polysaccharides isolated from green algae. Biochim. Biophys. Acta, 1543, 86-94.

Karnjanapratum, S. and You, S. (2011), Molecular characteristics of sulfated polysaccharides from Monostroma nitidum and their in vitro anticancer and immunomodulatory activities. Inter. J. Biol. Macromol., 48, 311-318.
Kjellèn, L. and Lindahl, U. (1991), Proteoglycans: structures and interactions. Annu. Rev. Biochem., 60, 443-475.

Kloareg, B. and Quatrano, R.S. (1988), Structure of the cell wall of marine algae and ecophysiological functions of matrix polysaccharide. Oceanogr. Mar. Biol. Annu. Rev., 26, 29299-29307.

Leite, E.L.; Medeiros, M.G.L.; Rocha, H.A.O.; Farias, G.G.M.; Silva, L.F.; Chanvante, S.F.; Abreu, L.D.; Dietrich, C.P. and Nader, H.B. (1998), Structure and pharmacological activities of a sulfated xylofucoglucuronan from the alga Spatoglossum schröederi. Plant Scien., 132, 215-278.

Lins, K.O.A.L.; Bezerra, D.P.; Alves, A.P.N.; Alencar, N.M.N.; Lima, M.W.; Torres, V.M.; Farias, W.R.L.; Pessoa, C.; Moraes, M.O. and Costa-Lotufo, L.V. (2009), Antitumor properties of a sulfated polysaccharide from the red seaweed Champia feldmannii (Diaz-Pifferer). J. Appl. Toxicol., 29, 2026.

Mansour, M.B.; Majdoub, H.; Bataille, I.; Roudesli, M.S.; Hassine, M.; Ajzenberg, N.; Chaubet, F. and Maaroufi, R.M. (2009), Polysaccharides from the skin of the ray Raja radula. Partial characterization and anticoagulant activity. Thromb. Res., 123, 671678.

Mao, W.J.; Fang, F.; Li, H.Y.; Qi, X.H.; Sun, H.H.; Chen, Y. and Guo, S.D. (2008), Heparinoid-active two sulfated polysaccharides isolated from marine green algae Monostroma nitidum. Carbohydr. Polym., 74, 834-839.

Masuko, T.; Minami, A.; Iwasaki, N.; Majima, T.; Nishimura, S.I. and Lee, Y.C. (2005), Carbohydrate analysis by a phenol-sulfuric acid method in microplate format. Anal. Biochem., 339, 69-72.

Matsubara, K.; Matsubara, Y.; Basic, A.; Liao, M. L. and Hori, K. (2001), Anticoagulant properties of a sulfated galactan preparation from a marine green alga Codium cylindricum. Inter. J. Biol. Macromol., 28, 395-399.

Matsubara, K.; Matsubara, Y.; Hori, K. and Miyazawa, K. (2000), An anticoagulant proteoglycan from the marine green alga, Codium pugniformis. J. Appl. Phycol., 12, 9-14.

Mazumder, S.; Ghosal, P.K.; Pujol, C.A.; Carlucci, M.; Damonte, E.B. and Ray, B. (2002), Isolation, chemical investigation and antiviral activity of polysaccharides from Gracilaria corticata (Gracilariaceae, Rhodophyta). Inter. J. Biol. Macromol., 31, 87-95.

Mourão, P.A.S. (2004), Use of sulfated fucans as anticoagulant and antithrombotic agents: future perspectives. Curr. Pharm. Des., 10, 967-981.

Mourão, P.A.S. and Pereira M. S. (1999), Searching for alternatives to heparin: sulfated fucans from marine invertebrates, Tren. Cardiov. Med., 9, 225-232. 
Melo, M.R.S.; Feitosa, J.P.A.; Freitas, A.L.P. and Paula, R.C.M. (2002), Isolation and characterization of soluble sulfated polysaccharide from the red seaweed Gracilaria cornea. Carbohydr. Polym., 49, 491-498.

Melo, F.R. and Mourão, P.A.S. (2008), An algal sulfated galactan has an unusual dual effect on venous thrombosis due to activation of factor XII and inhibition of the coagulation proteases. Thromb. Haemost., 99, 531-538.

Nader, H.B.; Pinhal, M.A.S.; Baú, E.C.; Castro, R.A.B.; Medeiros, G.F.; Chavante, S.F.; Leite, E.L.; Trindade, E.S.; Shinjo, S.K.; Rocha, H.A.O.; Tersariol, I.L.S.; Mendes, A. and Dietrich, C.P. (2001), Development of new heparin-like compounds and other antithrombotic drugs and their interaction with vascular endothelial cells. Braz. J. Med. Biol. Res., 34, 699-709.

Nishino, T.; Aizu, Y. and Nagumo, T. (1991), The influence of sulfated content and molecular weight of a fucan sulfate from the brown seaweed Ecklonia kurome. Thromb. Res., 64, 723-731.

Pereira, M.G.; Benevides, N.M.B.; Melo, M.R.S.; Valente, A.P.; Melo, F.R. and Mourão, P.A.S. (2005), Structure and anticoagulant activity of a sulfated galactan from the red alga, Gelidium crinale. Is there a specific structural requirement for the anticoagulant action? Carbohydr. Res., 340, 2015-2023.

Pereira, M.S.; Melo, F.R. and Mourão, P.A.S. (2002), Is there a correlation between structure and anticoagulant action of sulfated galactans and sulfated fucans? Glycobiol., 12, 573-580.

Percival, E. and McDowell, R. H. (1967), Chemistry and enzymology of marine algal polysaccharides. Academic Press, New York.

Pomin, V.H. and Mourão, P.A.S. (2008), Structure, biology, evolution, and medical importance of sulfated fucans and galactans. Glycobiol., 18, 10161027.

Pushpamali, W.A.; Nikapitiya, C.; Zoysa, M.D.; Whang, I.; Kim, S.J. and Lee, J. (2008), Isolation and purification of an anticoagulant from fermented red seaweed Lomentaria catenata. Carbohydr. Polym., 73, 274-279.
Qi, H.; Zhang, Q.; Zhao, T.; Chen, R.; Zhang, H.; Niu, X. and Li Z. (2005), Antioxidant activity of different sulfate content derivates of polysaccharide extracted from Ulva pertusa (Chlorophyta) in vitro. Inter. J. Biol. Macromol., 37, 195-199.

Rodrigues, J.A.G.; Torres, V.M.; Alencar, D.B.; Sampaio, A.H. and Farias, W.R.L. (2009a), Extração e atividade anticoagulante dos polissacarídeos sulfatados da alga marinha vermelha Halymenia pseudofloresia. Rev. Ciên. Agron., 40, 224-231.

Rodrigues, J.A.G.; Vanderlei, E.S.O.; Queiroz, I.N.L.; Quinderé, A.L.G. and Benevides, N.M.B. (2009b), Purificação e atividade anticoagulante de glicosaminoglicanos isolados da pele da carpa comum, Cyprinus carpio. Rev. Ciên. Agron., 40, 381387.

Rodrigues, J.A.G.; Júnior, J.J.; Lourenço, J.A.; Lima, P.C.W.C. and Farias, W.R.L. (2009c), Cultivo de camarões tratados com polissacarídeos sulfatados da rodofícea Halymenia pseudofloresia mediante uma estratégia profilática. Rev. Ciên. Agron., 40, 71-78.

Rodrigues, J.A.G.; Araújo, I.W.F.; Paula, G.A.; Lima, T.B.; Bessa, E.F.; Benevides, N.M.B. (2011), Carragenana da epífita Hypnea musciformis obtida do cultivo experimental de Solieria filiformis em Flecheiras, Estado do Ceará, Brasil. Acta Scien. Technol., 33, 137-144.

Salles, J.P.; Scherner, F.; Yoshimura, Y.; Fanganiello, M.; Bouzon, Z.L. and Horta, P.A. (2010), Cultivation of native seaweed Gracilaria domingensis (Rhodophyta) in Southern Brazil. Braz. Arch. Biol. Technol., 53, 633-640.

Zhang, H.J.; Mao, W.J.; Fang, F.; Li, H.Y.; Sun, H.H.; Chen, Y. and Qi, X.H. (2008), Chemical characteristics and anticoagulant activities of a sulfated polysaccharide and its fragments from Monostroma latissimum. Carbohydr. Polym., 71, 428-434.

Received: August 06, 2009; Revised: July 29, 2010; Accepted: February 02, 2011. 